\title{
Relevance of Civic Education With the Awareness in Building National Resources as the Embodiment of the National Defense
}

\author{
Seriwati Ginting, Miki Tjandra, Hendra Setiawan \\ Fakultas Seni Rupa dan Desain Universitas Kristen Maranatha \\ seriwati.ginting@maranatha.edu
}

Received: 26 April 2021; Revised: 16 July 2021; Accepted: 13 August 2021
DOI: $\underline{\text { http://dx.doi.org/10.37905/aksara.7.3.927-936.2021 }}$

\begin{abstract}
Abstrak
Pendidikan Kewarganegaraan mengajarkan nilai-nilai hidup yang terwujud dalam perilaku sehari-hari, seperti menerima keberagaman bangsa Indonesia. Masih adanya ujaran kebencian dan sikap saling menyalahkan menjadi cerminan kegagalan berbangsa. Penelitian bertujuan mengembangkan mata kuliah Pendidikan Kewarganegaran agar mampu menumbuhkan kesadaran mahasiswa untuk menjadi warga negara yang baik dan terdidik. Metode deskriptif kualitatif mengkaji dan menganalisis pemahaman mahasiswa tentang relevansi Pendidikan Kewarganegaraan dengan sumber daya nasional yang terwujud dalam ketahanan negara. Temuan dari penelitian memperlihatkan sebagian mahasiswa menyadari adanya keterkaitan antara pendidikan kewarganegaraan dengan sumber daya manusia namun keteladanan dari tenaga pendidik, tenaga kependidikan, pemuka agama, tokoh politik, dan tokoh masyarakat masih kurang.
\end{abstract}

Kata kunci: ketahanan negara, Pendidikan Kewarganegaraan, sumber daya nasional.

\begin{abstract}
Civic Education teaches the values of life that are manifested in daily behavior, such as accepting the diversity of the Indonesian nation. The existence of hate speech and blaming each other is a reflection of the failure of the nation. This research aims to develop Civic Education courses so that they can raise students' awareness to become good and educated citizens. Qualitative descriptive method examines and analyzes students' understanding of the relevance of Civic Education with national resources embodied in state resilience. The findings from this study show that some students are aware of the relationship between civic education and human resources but the role models of educators, education staffs, religious leaders, political leaders, and community leaders are still lacking.
\end{abstract}

Keywords: Civic Education, national resources, state resilience.

\section{Introduction}

Civic education, as a personality development course with a main focus on the affective aspect, builds and develops the character of students. Character development 


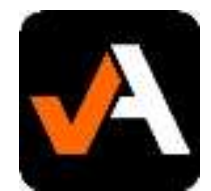

AKSARA: Jurnal Ilmu Pendidikan Nonformal

P-ISSN 2407-8018 E-ISSN 2721-7310 DOI prefix 10.37905

Volume 07, Issue 03 September 2021

http://ejurnal.pps.ung.ac.id/index.php/Aksara

is aimed at fostering nationalism, defending the country, love for the homeland and the realization of smart and good citizens. The national stability that has been built will be damaged by the citizens who lack awareness of the diversity of their nation (Ministry of Education and Culture, 2017). Various events that occur and develop in the country such as the attitude of not being able to accept differences, intolerance, selfaggrandizement, bullying, indifferent, apathy, hate speech, instant culture, fake certificates, cheating, plagiarism, indicate a shift in values and norms. It was specifically found that some lecturers and alumnies were involved in practical political demonstrations in regional head elections, making and distributing hate speech videos through social media.

Juridically as stated in Law No. 12 of 2012, religious education, Indonesian language, Pancasila education, and civic education are subjects that must be given at all types and levels of education. The values contained in the civic education material should manifest in the mindset, attitudes, and actions that refer to the value order that is owned and rooted in the nation's cultural values so that various changes that occur especially in the era of globalization do not erode national values (Hendarman, 2019: 5 ). The existence of civic education as a means of fostering national character (nation and character building) is very important and has a strategic role. Civic education in higher education is more at the affective level because the cognitive aspect has been studied since elementary school, which then develops, grows according to the maturity of students (Ginting, 2020).

The mission of the personality development course is to help students strengthen their personalities to think critically, have broad insight, accept differences as a nation's reality (Jamaludin, 2017: 4). Through various activities held on campus, they condition them to accept the reality of life in diversity. The campus as the last bastion instills national values, humanity, and respect for differences and diversity guards the truth in society and the production of knowledge is born and must be sterile from the interests of power politics, money, let alone betrayal of science.

Since the issuance of the Law on the Empowerment of National Resources (SDN) which is regulated in Law no. 23 of 2019, it has further strengthened the importance of growing awareness in students as part of national resources. National resources consist of Human Resources (HR), Natural Resources (SDA), and Artificial Resources (SDB). The human resource factor is very important, therefore advancing the nation in the midst of increasingly fierce global competition must be done through strengthening people's mentality (Hendarman, 2019: 3). It is undeniable that the journey of a nation is not free from various threats. There are threats and challenges that come from within the country and also from abroad. Various events occurred, such as the destruction of houses of worship, terror bombs, the proliferation of fake news/hoaxes, and words that decried each other. It is very important for the younger generation to be literate so that not all information is received but sorted, selected based on real data and facts (Ministry of Education and Culture, 2017). This shock tore apart the identity of the Indonesian nation as a peaceful nation with the motto Bhinneka Tunggal Ika. The government needs to review various policies that are used as a reference for living together as a nation. Policies at the local level tend to ignore tolerance and diversity (Rozi, 2017: 2).

The main things that must be answered in realizing the dynamic condition of the nation include tenacity, resilience, and deterrence to face threats, challenges, obstacles, 
and disturbances (ATHG) to the identity, integrity, and survival of the nation so that the ideals and goals of the state can be realized (Nugroho, 2019: 8).

The ideals and goals of the state can be realized if all components of the nation participate in defending the country. Defending the country has many varieties and types. Physical defense of the country is like, "bearing arms" in the face of enemy attacks or aggression. Non-physical state defense is all efforts to defend the unitary state of the Republic of Indonesia by increasing awareness of the nation and state, instilling the love of the homeland, one of which is realized by being aware and obedient in paying taxes (Ristekdikti, 2016: 273).

\section{Method}

The method used in this study is a combination method. Emphasis on qualitative descriptive analysis, with meaning and case studies through natural settings, distribution, and processing of questionnaires as part of quantitative research (Sugiyono, 2014: 27). Data collection techniques were carried out through interviews, documentation, and triangulation patterns. The Pandemic situation began to occur while the research was in progress, so some interviews were conducted online. Interviews were conducted with civic education lecturers, the Education Institute for the Directorate of Student Affairs, and students. There were three hundred and six students who filled out the questionnaire. The results of the questionnaire were processed and displayed in the form of tables and graphs.

\section{Results and Discussion}

The existence of civic education as a personality development course has an important and strategic role in shaping character. Character is the basic thing, which helps a person to be consistent with thoughts, words, and actions. Many smart people are successful but take shortcuts and eventually end up with the arrest of the KPK, smart people but then it is known that their certificates are fake. Some became jockeys, provocateurs and were involved in brawls between students, some students faked the lecturer's signature. All this shows a lack of character in the person. Character education is nothing new. Ki Hajar Dewantara as the Father of Indonesian Education stated that education is an effort to cultivate character, mind (intellect), and body, all three must become one unit. Character education is a process of humanization in the context of humanizing humans to be human. Character education actually cannot be separated from education programs in general. Educating the mind without educating the hearts is not education (Aristotle in Badudu, 2019: 99). In the era of globalization, the challenges of nationalism are getting tougher because of the two major biases, namely the globalization bias which tends to ignore the boundaries of the nation-state, and the bias from within in the form of a tendency to strengthen narrow ties such as ethnic, tribal or regional ties (Ristekdikti, 2016: 89).

Globalization that is not fortified with knowledge and national insight about the importance of the national defense system has an impact on a misunderstanding of the role and function of students as part of citizens. The universal nature of national defense is based on awareness of the rights and obligations of citizens and belief in one's strength. State defense and security are important for the survival of the nation and state and are the absolute responsibility of all components of the nation. Law Number 3 of 
2002 concerning national defense as stated in Article 1 point 1 is stated that national defense is all efforts to defend the sovereignty of the state, and the territorial integrity of the Unitary State of the Republic of Indonesia. National resilience is essentially a condition that describes the nation's ability to overcome all kinds of challenges, obstacles, and disturbances. The values contained in civic education related to awareness of building national resources are grouped into three parts that synergize with ICE values at Maranatha Christian University.

Integrity values include (1) Awareness to study the history of the Indonesian nation, (2) Awareness of defending the country, (3) Awareness of carrying out rights and obligations in a balanced way, (4) Injustice is a common enemy, (5) Awareness and willingness to accept pluralism as a part of being inseparable (6) Awareness and willingness to follow and obey the established rules.

Care values include (1) Everyone is part of national resources, (2) National resilience starts from oneself, (3) Non-physical threats need to be realized and watched out for, (4) Attention and concern for government recommendations during a pandemic (using the mask, keeping distance, washing hands frequently) and being willing to share with victims of the pandemic, (5) Placing oneself wisely, being able to distinguish between the private and public spheres in expressing opinions.

Excellent values include (1) Enthusiasm in doing every task as well as possible, (2) Innovative, continuing to explore self-potential and develop oneself to the fullest, (3) Consistent, learn and practice the real value of course material, (4) Initiative, following the development of technology and information, (5) Futuristic, understanding Trigatra and Pancagatra and their implementation efforts towards a more advanced Indonesia.

\section{Results}

Good character does not just happen, there needs to be a process, effort, and ability to do it. Character is a combination of habits. Habits can be interpreted as patterns for responding to certain situations that are learned by an individual and are carried out repeatedly (Big Indonesian Dictionary). The focus is on application and not on knowledge. Implementation needs to be supported by all components involved in it and facilitated by relevant educational institutions. Maranatha carries three values, namely Integrity, Care, and Excellent (ICE).

\section{A. The Value of Integrity}

Integrity comes from the word integer which means one, whole, and not broken. Everyone is expected to have this. Its implementation appears in behavior (the compatibility between thoughts, words, and actions). Lecturers are the lead in relating and integrating with students and education staff. Lecturers are not only qualified or skilled in delivering lecture material but should be an example or reference for their students so that every moral message is not only known in words but is consistently applied in daily life. Students with idealism need an example. Not only in knowledge but also in speech and action. Through questionnaires and interviews, answers were obtained that there was still a gap between speech and action. Some examples presented include the results of assignments not always being announced, sudden schedule changes, and education staff not always being responsive. 
The results of interviews with lecturers obtained that the answers were still found among students who did not submit assignments on time. The answer to the student's assignment is the same, it is too late to join Zoom so that information about the material and assignments received by students is incomplete. When attending lectures using $\mathrm{ms}$ team, the student's name is listed as a participant but when his name is called they are not there. An unstable network is a reason. Apart from that, the character is realized as a process that requires awareness from every individual. Awareness that is followed up in word and deed. Nobody is perfect. The more a person knows himself and knows his strengths and weaknesses, the more ready he is to accept the existence of others. Therefore, character education focuses on individual growth. Character is a sign of personality that characterizes each person (Badudu, 2019). A complete and comprehensive character education completes the calling of man in history as an agent for change in himself and society. Habits that are done repeatedly become spontaneous, without thinking or feeling. The survival and existence of a nation are greatly influenced by the nation's ability to understand and master the geographical foundations and the surrounding environment (Suryohadiprojo, 2020).

Transfer of knowledge related to Law number 23 of 2019 concerning the management of national resources for defense, needs to be followed up in class discussions, asking questions, and through assignments. That every citizen has the right and obligation to participate in national defense and security efforts as mandated in the 1945 Constitution of the Republic of Indonesia. At this point, almost eighty percent of students agree that every citizen has rights and obligations in national defense efforts. However, when asked to name the forms of state defense, it was found that for the physical defense of the country, all answered correctly. For non-physical state defense, only a small part can answer. There is a gap in thinking that physically defending the country is seen as the main thing. Four important points must be conveyed in the class, namely global awareness; financial, economic, business, and entrepreneurial literacy awareness; awareness as a citizen of the nation; and awareness of health and wellness (Triling and Fadel in Samani, 2019: 38). This explanation is expected to be one of the topics presented by each lecturer in raising awareness of each student to think globally while still based on national values. In the following, the answers to the questionnaire and interviews are grouped into three parts. The following table is the respondents' answers to the values of Integrity. 
AKSARA: Jurnal Ilmu Pendidikan Nonformal

P-ISSN 2407-8018 E-ISSN 2721-7310 DOI prefix 10.37905

Volume 07, Issue 03 September 2021

http://ejurnal.pps.ung.ac.id/index.php/Aksara

Table 1 The Value of Integrity

\begin{tabular}{llccc}
\hline NO. & QUESTION & AGREE & DOUBTFUL & DISAGREE \\
\hline 1 & $\begin{array}{l}\text { Awareness to study the history of } \\
\text { the Indonesian nation. }\end{array}$ & $75 \%$ & $23 \%$ & $2 \%$ \\
2 & $\begin{array}{l}\text { National defense awareness. } \\
3\end{array}$ & $80 \%$ & $19 \%$ & $1 \%$ \\
& $\begin{array}{l}\text { Awareness of carrying out rights } \\
\text { and obligations in a balanced } \\
\text { manner. }\end{array}$ & $77 \%$ & $20 \%$ & $3 \%$ \\
4 & $\begin{array}{l}\text { Injustice is our common enemy. } \\
\text { Awareness and willingness to }\end{array}$ & $55 \%$ & $36 \%$ & $9 \%$ \\
accept diversity. & $85 \%$ & $13 \%$ & $2 \%$ \\
6 & Awareness to obey the rules. & $90 \%$ & $9 \%$ & $1 \%$ \\
\hline
\end{tabular}

(Source: Questionnaire Results)

The table above shows that in general, the student's answers to the theoretical level, knowledge of student awareness is very good, except in addressing the question of injustice as a common enemy. Through interviews, the answers were obtained, that some students were still confused because of the many cases that had not been handled and there were still cases that in their view the punishment given was inappropriate. Some examples that were revealed were the case of a grandmother who stole cocoa and a teenager who stole sandals with too severe a penalty. The answers given by the students are an indication that they care about and follow the phenomena that occur in society.

\section{B. The Value of Care}

The value of Care begins with the awareness that everyone is part of a national resource. Care for nationality is explored by asking students to mention the national anthem along with the name of the songwriter, the meaning contained in it, and its application in the life of the nation and state. This task is then presented. So that students find out so that their knowledge increases and fosters a deeper sense of knowing the meaning of the national anthem and the messages contained in it. Students' concern for national security begins with themselves and then the environment. For the environment around the campus, it was carried out by conducting a survey (before the Covid-19 pandemic) on the people living in the campus environment. By conducting interviews with RT, information is obtained about the condition of the community which includes; the number of children and the age of the children, the number of financially disadvantaged people, what kind of training is it possible for residents to open up new opportunities as businesses with small capital. School-age children are divided into several groups, according to their specialization. Such as drawing/painting groups, music groups, language groups. Furthermore, mothers in collaboration with art lecturers were given the training to make clothes without a pattern (no sewing machine needed) and for fathers, they were given training in making liquid fertilizer with easily available materials. 
Table 2 The Value of Care

\begin{tabular}{llccc}
\hline NO. & QUESTION & AGREE & DOUBTFUL & DISAGREE \\
\hline 1 & $\begin{array}{l}\text { Everyone is part of the national } \\
\text { resources. }\end{array}$ & $89 \%$ & $9 \%$ & $2 \%$ \\
2 & $\begin{array}{l}\text { National resilience starts from } \\
\text { oneself. }\end{array}$ & $92 \%$ & $8 \%$ & $0 \%$ \\
3 & $\begin{array}{l}\text { Caring for phenomena in the } \\
\text { environment. }\end{array}$ & $77 \%$ & $18 \%$ & $5 \%$ \\
4 & $\begin{array}{l}\text { Non-physical threats need to be } \\
\text { watched out. }\end{array}$ & $75 \%$ & $23 \%$ & $2 \%$ \\
5 & $\begin{array}{l}\text { Adhere to government advice. } \\
\text { Position yourself wisely in private } \\
\text { realm and domestic realm. }\end{array}$ & $83 \%$ & $12 \%$ & $3 \%$ \\
\hline
\end{tabular}

(Source: Questionnaire Results)

The table above illustrates that the points related to national resilience, selfawareness as part of national security, awareness that national resilience starts from oneself (referring to the concept of layered resilience) is very good. What still needs emphasis is on non-physical threats. In globalization, a country without borders on nonphysical threats such as the proliferation of foreign cultures and being loved by students can erode the original culture of Indonesia. It is necessary to revive various regional arts through various events held, so that social culture as part of national resilience can be maintained. Meanwhile, students' awareness of placing themselves correctly when in public spaces needs to be fostered, reminded to be able to maintain and maintain unity and integrity. Everything related to SARA needs to be "cautious" so as not to cause friction.

\section{The Value of Excellence}

The value of excellence is applied to sincerity in carrying out every action. Through lecturer assignments, it can be seen the seriousness of students in working. The findings are conveyed to students through writing on the answer sheet or during a pandemic, lecturers can contact students personally. Forming a character is not easy. The assumption that students are adults so there is no need for detailed instructions is not entirely true. They still need exemplary. The following is a table of the excellence values.

Table 3 The Value of Excellence 
AKSARA: Jurnal Ilmu Pendidikan Nonformal P-ISSN 2407-8018 E-ISSN 2721-7310 DOI prefix 10.37905

Volume 07, Issue 03 September 2021

http://ejurnal.pps.ung.ac.id/index.php/Aksara

\begin{tabular}{|c|c|c|c|c|}
\hline NO. & QUESTION & AGREE & DOUBTFUL & DISAGREE \\
\hline 1 & $\begin{array}{l}\text { Enthusiastic, doing every task as } \\
\text { well as possible. }\end{array}$ & $90 \%$ & $10 \%$ & $0 \%$ \\
\hline 2 & $\begin{array}{l}\text { Innovative, explore potential to } \\
\text { the fullest. }\end{array}$ & $85 \%$ & $12 \%$ & $3 \%$ \\
\hline 3 & $\begin{array}{l}\text { Consistent, practice every value } \\
\text { that has been learned. }\end{array}$ & $77 \%$ & $23 \%$ & $0 \%$ \\
\hline 4 & $\begin{array}{l}\text { Initiative, keeping up with } \\
\text { advances in technology and } \\
\text { information. }\end{array}$ & $86 \%$ & $23 \%$ & $1 \%$ \\
\hline 5 & $\begin{array}{l}\text { Futuristic, knowing and } \\
\text { understanding Trigatra and } \\
\text { Pancagatra towards a more } \\
\text { advanced Indonesia. }\end{array}$ & $85 \%$ & $13 \%$ & $2 \%$ \\
\hline 6 & $\begin{array}{l}\text { Total, doing something } \\
\text { completely. }\end{array}$ & $85 \%$ & $13 \%$ & $2 \%$ \\
\hline
\end{tabular}

(Source: Questionnaire Results)

The excellence table overall shows very good results. Through interviews, answers were obtained that this happened because of environmental influences, the influence of influential people around them. It is revealed through civic education that everyone prioritizes unity and integrity, respects each other, obeys the rules, respects differences, but in everyday life, especially through social media, they see that there are still many figures who should set an example, give soothing statements but often trigger the emergence of various hate speeches". Students need to be made aware that ideal figures are those who have high nationalism and good character. If in reality there are things that are not in line with expectations, students should have attitudes and principles so that they can continue to follow and apply all the good values that have been learned.

\section{Summary}

Adult education, referred to as andragogy comes from the Greek words andra (adults) and agogos (leading). Adult education aims to organize a systematic and continuous learning activity to change knowledge, attitudes, values, and skills. Campus life basically can be used as a reference in the life of the nation and state because the campus world is very open to diversity. According to the authors, there needs to be an effort from the campus to organize activities of national insight in addition to civic and Pancasila education lectures, or in various state, ceremonies commemorated such as the birthday of the term Pancasila, Youth Pledge Day, National Awakening Day, etc.

The national resilience strategy begins with the awareness to love one's own culture. The process of loving that is carried out consciously and continuously grows and at the same time instills a sense of pride in the culture one has. Because the national resilience of a country is strongly influenced by many factors and one of them is sociocultural factors.

This study found that students' awareness of the importance of national resources was quite good, but the role model still did not represent the expected number. The law on national resources is relatively new, so at the time this research was conducted it had 
not yet been included in the RPS. There has been a growing awareness that defending the country can be carried out by all components of the nation's children, including students. Dispose of garbage in its place, turn off water and electricity that is not used and participate in maintaining environmental cleanliness by not scribbling on walls, become a volunteer teacher for disadvantaged children, provide training to housewives and unemployed fathers by cooperating with lecturers from qualified products. For example, providing training to make clothes without patterns by cooperating with lecturers from Fashion Design for marketing, collaborating with lecturers from business study programs (which opens up income opportunities).

National resources do not stand alone. Influenced by aspects of ideology, politics, economy, socio-culture and defense and security. Of all the things mentioned above, it turns out that human capital plays the most decisive role. Smart and good citizens are the targets of civic education. This can be realized if there is awareness from every citizen to become a citizen generator. Take an active role as a generator making many breakthroughs and innovations and at the same time as a supporter of various government policies and programs. Not only as a sponge that absorbs or accepts every policy but is willing to criticize and support. The soft skill factor as a complement to the hard skill is carried out in a balanced way. The balance of all Astagatra factors in the context of national and state life supports the realization of national resources. National resources still have to be disseminated to all levels of society.

\section{References}

Badudu, R. (2019). Character Excellence, Mengembangkan Karakter Pribadi. Jakarta: Kompas Media

Nusantara.

Direktorat Jenderal Pembelajaran dan kemahasiswaan. (2016). Pendidikan

Kewarganegaraan untuk

Perguruan Tinggi. Kementerian Riset Teknologi dan Pendidikan Tinggi.

Ginting, S., Tjandra, M., \& Setiawan, H. (2020). The Role of Civic Educations in Developing Student's

Nationalism. Variety of Learning Resolutions in the Covid 19. India: Novateur

Publication. https://novateurpublication.com/index.php/np/catalog/book/11

Hendarman. (2019). Pendidikan Karakter Era Milenial. Bandung: Remaja Rosdaya.

Irianto, S. (2021). Matinya Universitas. Fakultas Hukum Universitas Indonesia.

https://law.ui.ac.id/v3/matinya-universitas-sulistyowati-irianto-harian-kompas/

Jamaludin, U. (2017). Pembelajaran di Sekolah Dasar Berbasis Pada Pertumbuhan dan Perkembangan

Peserta Didik. DOI: https://dx.doi.org/10.30870/JPsd.v1i1.708

Kementerian Pendidikan dan Kebudayaan. (2017). Literasi Budaya dan Kewarganegaraan. Gerakan

Literasi Nasional. https://gln.kemdikbud.go.id/glnsite/wpcontent/uploads/2017/10/cover-materi-pendukung-literasi-budaya-dan-kewargaangabung.pdf

Law of the Republic of Indonesia Number 3 of 2002 concerning The National Defense. (2002) 


\section{AKSARA: Jurnal Ilmu Pendidikan Nonformal \\ Volume 07, Issue 03 September 2021 P-ISSN 2407-8018 E-ISSN 2721-7310 DOI prefix 10.37905 \\ http://ejurnal.pps.ung.ac.id/index.php/Aksara}

Law of the Republic of Indonesia Number 12 of 2012 concerning Higher Education. (2012)

Law of the Republic of Indonesia Number 23 of 2019 concerning National Resource Management. (2019)

Nugroho, A. (2019). Menggalang Ketahanan Nasional dengan Paradigma Pancasila. Jakarta: Kompas

Media Nusantara.

Ristekdikti. (2016). Pendidikan Kewarganegaraan untuk Perguruan Tinggi. Direktorat Jenderal

Pembelajaran dan Kemahasiswaan Kementerian Riset, Teknologi dan Pendidikan Tinggi Republik Indonesia.

Rozi, S. et al. (2019). Nasionalisme dan KeIndonesiaan di Perbatasan. Yogyakarta: Suluh Media.

Samani, M. \& Hariyanto. (2019). Konsep dan Model Pendidikan Karakter. Bandung: Remaja Rosdaya.

Sugiyono. (2014). Metode Penelitian Kombinasi (Mixed Methods). Bandung: Alfabeta. Suryohadiprojo, S. (2014). Mengobarkan Kembali Api Pancasila. Jakarta: Kompas Media Nusantara. 